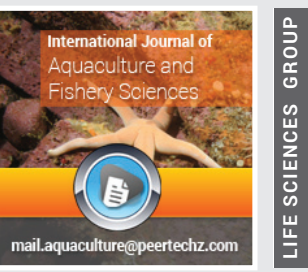

\section{Moshe Gophen*}

MIGAL Scientific Research Institute, POB 813 Kiryat Shmone, (11016), Israel

Received: 02 May, 2019

Accepted: 25 June, 2019

Published: 26 June, 2019

*Corresponding author: Moshe Gophen, MIGAL Scientific Research Institute, POB 813 Kiryat Shmone, (11016) Israel, E-mail: Gophen@Migal.org.il

Keywords: Phytoplankton; Zooplankton; Body; Cell size; Temperature; Fish feeding

https://www.peertechz.com

Check for updates
Review Article

The impact of fish feeding habits and thermal conditions on plankton body size fluctuations: Commentary perspective

\section{Introduction}

During the last 80 years the Lake Kinneret and its drainage basin has undergone significant changes. Some of those changes are natural and others are anthropogenic: dam construction (1933), salty water diversion (1967), salinity fluctuations, National Water Carrier construction (1957), fish stocking and fisheries management, long term decline and increase of water level, droughts and floods, modification of Phytoplankton biomass and species composition, beach vegetation. Nitrogen decline and a slight increase of Phosphorus in the lake epilimnion; decline of nitrogen loads in the Jordan River; Decline of the Epilimnetic N/P mass ratio, followed by enhancement of Cyanobacteria. The Kinneret ecosystem shifted from $\mathrm{P}$ to $\mathrm{N}$ limitation. Climate change, (global warming) was recently widely indicated, but was not intensively considered as a parameter of pollution condition. The present paper is an attempt at evaluation of the ecological modifications in the Lake Kinneret ecosystem including thermal fluctuations and their implications on phytoplankton cell size features.

Plankton research uncovered an apparent contradiction in the seasonality of body size between Phytoplankton and Zooplankton response: Phytoplanktes are larger in winter and smaller in summer, whilst zooplankters represent the opposite. The relation between body size of planktonic (Phytoplankton, Zooplankton) organisms and temperature was widely studied.
A comparative study of the heat balance in Poikilotherm and Homeotherm organisms was documented by Peter, Thiel $[1,2]$ related the dominance of smaller organisms in deepsea benthic communities and hypothesized that the reduced level of resource supply is the reason for that. The relation between insufficient food resources and the small body size of zooplankton was also documented by Threlkeld, Kilham and Kilham and Semina [3-5]. Those relative causations are probably insufficient since several other parameters are probably involved. The other parameters include biotic and A-biotic traits. Among A-biotic factors the difference between specific gravity of planktonic organisms with low motility ability as related to water temperature has a significant impact on their sinking rate due to drag and viscosity forces modifications (Stoke's Law) and, therefore, affect the frequency distribution of body size classes. Moreover, morphological shape and appendages, as well as surface area relative to body volume of the planktonic organisms, also significantly affect sinking rate and, consequently, size class distribution. Among biotic parameters, the presence of plankton predators and/or herbivores, diurnal vertical migration, fluctuations of light condition, metabolic trait alterations in relation to thermal changes and others are highly involved as well. Diurnal fluctuations of phytoplanktonic photosynthetic activity and colonial aggregation also have an impact on body size changes. Lake Kinneret is a suitable body of water for the evaluation of these parameters and their impact on the Ecosystem because 
of the long term record of limnological parameters and the significant national and international importance of the lake.

\section{Nutrients in lake kinneret}

The multiannual mean ranges of the concentration, ph of the major nutrient concentrations (ppm) and $\mathrm{pH}$ and Electrical Conductivity (EC) (mS) in the Epilimnion of Lake Kinneret are given in the next Table 1.

Table 1: Nutrients in lake kinneret.

\begin{tabular}{|c|c|}
\hline Nutrient & Concentration (ppm) \\
\hline $\mathrm{pH}$ & $7.4-8.9$ \\
\hline EC & $1501-1167$ \\
\hline Sulfide & 0 (Hypolimnion: 3-9) \\
\hline Chloride & $250-300$ \\
\hline Total Nitrogen & $0.5-0.8$ \\
\hline Ammonium Nitrogen & $0.02-0.08$ \\
\hline Nitrate Nitrogen & $0.06-0.7$ \\
\hline Total Phosphorus & $0.01-0.02$ \\
\hline Total Dissolved Phosphorus & 0.01 \\
\hline Organic Nitrogen & $0.3-0.7$ \\
\hline Organic Carbon & $3.0-4.0$ \\
\hline Silica & $4.0-7.0$ \\
\hline Sulfate & $51-56$ \\
\hline Calcium & $37-48$ \\
\hline
\end{tabular}

The temporal distributions of plankton and nutrients was considered as two annual periods: January-June nominated as "winter" (including winter and spring months) and July December"summer" (including summer and fall months).

\section{Physical aspects of floating}

A recent presentation entitled "Being smaller in Summer, larger in Winter: a general pattern in Freshwater Phytoplankton" [6], attributed Phytoplankton body size fluctuations to seasonal Temperature changes and Stokes' Law Respective Consequences. Stokes' law describes the viscosity or drag force (Fd) which is activated on a spherical particle moving inside a viscose fluid media and expressed as:

$\mathrm{Fd}=6 \pi \eta \mathrm{Rv}$;

Where:

Fd= Frictional force; Stokes' Drag;

$\eta$ = Dynamic Viscosity (also $\mu$ is used);

$\mathrm{R}=\mathrm{The}$ radius of the spherical particle;

$\mathrm{v}=$ Flow velocity relative to the spherical object;

Difficulties in implementing Stokes' law to natural conditions of Plankton behavior are due to the following independent factors of Stokes' Law:
1) The flow velocity relative to the spherical object;

2) The particle is spherical with a smooth surface;

3) The fluid media is homogenous;

4) Particles presented in the system do not interfere with each other;

Nevertheless, the integration of Stokes' Law within natural size composition of plankton and thermal condition is limited. The reason is partly that none of the conditions assumptions of Stokes' Law existed completely. Stokes' Law can be fully validated in a system where the viscosity is dominant on gravity (Inertia) with small Reynolds number (Re). A smaller Re indicates low and turbulent flow while a bigger Re indicates a laminar flow. Stokes' Law is less relevant if the flow (around the particle) is turbulent (not Laminar) with vortex around it as common in nature. The ability of a particle to float is fluid specific gravity- and viscosity-dependant. Three forces control the float/sink behavior of a planktonic organism: gravity, lifting and the fluid resistance. Stokes' Law is relevant to the differences between sinking sphere shaped particle weight and settling velocity. Stokes' Law is inappropriate for particle shaping varieties and/or appendage development as well as cells aggregation. The scope of settling the dynamics of Filamentous Phytoplankters and thermal impact on cell sizes is, at least, out framed from Stokes' Law consideration. In fact, without any relation to thermal condition, the density of the filaments (Diatoms, Chlorophytes, Cyanophytes) in the upper layers is efficiently controlled by another dominant factor, the wind velocity and stormy conditions. If the filaments are abundant and wind velocity is high, the initiation of upper water turbulence (or even upwelling case) is carried out and the filaments do not settle and cell size impact is minor and similar during summer and winter storms. This is the reason freshwater and marine Algal morphology can be both considered within the scope of Stokes' Law. Significant examples are the freshwater and marine Dinoflagellate algae ( $>90 \%$ are marine species) represented In Lake Kinneret as the bloom forming Peridinium gatunense and Ceratium hirudinella and the marine "Red Tide" Bloom of Goyaulax (Alexandrium sp., Lingulondinium sp.). The Dinoflagellates property of having two flagella partly prevent the incorporation of Stokes' Law within the analysis of thermal impact on cell size and settling dynamics: the function of those falagella is to propel the cells through the water column up and downward on an hourly basis. It is a trait of adaptation to nutrient availability, light intensity and thermal conditions. It is likely that long-term analyses of temperature impact on cell size and/or settling dynamics (Stokes' Law) of motile Dinoflagellates are, therefore, biased.

Moreover, the "armored" feature of Dinoflagellates as rigid Polysaccharide plates (Theca) is an exceptional factor when the diurnal or seasonal cascading effect of grazing intensity and/ or selectivity are included in the study of thermal impact on cell size classes frequent distribution as a part of the entire phytoplankton assemblages.

\section{Fish and fishery in lake kinneret}

The Native assemblages of Lake Kinneret fishes include 
19 species of which about 10 are commercially fished and 5 are endemic [7]. The offshore open water (>3m depth) community structure differ significantly from the inshore shallow habitats. Nevertheless there is a prominent occasional migration and location changes between the shallows and open water allocation. The permanent population in the shallows is mostly due to small-sized fishes whilst large adult specimens migrate to the inshore zone during the spawning period and sporadically to feed on a daily basis when temperatures are suitable. Those summer (when daily minimum of shallow water temperature is not below $21^{\circ} \mathrm{C}$ ) migratory species are nest builders and mouth breeders $[8,9]$. In winter periodical (4-10 days cycle), shoals of bleaks inhabiting the shallows at night and as free mixed (Males and Females) swimmers release more eggs and sperms than fertilized eggs adhered to stones for incubation. Mating performance, nest constructing, mouth-breeding and YOY (young of the year) training are carried out in the shallows whilst feeding in offshore waters $[8,9]$. The majority of the Kinneret fishes are planktivores of which several are particulate attackers (Particle size selection); the others are filter feeders (all size frequencies ingestion), and piscivory is minimal. A smaller number of species (Barbels) are bottom dwellers, stone scrapers and piscivory is rare [10] The most abundant feeding habit of the permanent population of small fishes in the shallows are bottom feeders. In spite of distinguished partitioning between food composition compartment among fish groups, there is a high level of interspecific overlap. Moreover, a natural shift from the majority of certain food sources to others was caused by the long-term ecological modification of the ecosystem.

\section{Feeding habits}

If fish feeding habits are discarded the impact of thermal elevation on the metabolic trait of phytoplankton and zooplankton and consequently on cell or body size is not significantly different: the results of physical and the physiological trait impacts are closely related. Nevertheless, ecological analysis of natural cell or body size desire an incorporation of prey consumption impact of fish on both Phyto and Zoopalnkton as well as algal grazing by zooplankton. Among the known diversities of the feeding behavior of Zooplanktivorous fish, two types are common: Filter feeders and particulate visual attackers. The filter feeder fishes ingest non-selective size particles. The particulate feeders select the larger organisms because "larger sizes are better indicated" and, therefore, more vulnerable. The ingestion rate and selective efficiency of food particles by fish as part of their total activity (swimming, respiration, digestion, excretion etc.) is temperature-dependent. The plankton size frequency is therefore affected by thermal condition: under lower winter temperatures the rate is slower and the opposite is typical for summer. Moreover, seasonality of feeding activity is not necessarily related to food item availability or thermal conditions. During reproduction activity of tropical mouth-breeder fishes, such as common cichlids in Lake Kinneret, in summer, they ceased feeding. The increased summer temperature induces spawning activity consequently accompanied by the stoppage of feeding. Nevertheless, Palaearcticoriginated fish species such as two common cyprinids species in Lake Kinneret, which reproduce in winter, maintain a very intensive feeding pressure in summer. The outcome of a species-versatile fish community inhabiting an ecosystem is an intensive elimination of small-bodied zooplankton organisms in summer, causing the dominance of large body zooplankters. The attempt to define the complexity of the plankton body size diversity as "smaller in summer and larger in winter", is therefore misleading.

The food composition of the Kinneret fishes was analyzed microscopically and by experimental studies [11-21]. A earlier collected data is due to the following species(families are indicated):

Cichlidae: Sarotherodon galilaeus, Oreochromis aureus, Coptodon zillii, Tristramella simonis simonis, Tristramella sacra, Astatotilapia flaviijosephi.

Cyprinidae: Luciobarbus longiceps, Carasobarbus canis, Capoeta damascina, Bleaks (Acanthobrama terraesanctae terraesanctae, Acanthobrama lissneri), Garra jordanica, Hemigrammocapoeta nana, Pseudophoxinus kervillei, Cyprinus carpio, Hypophthalmichthys molitrix.

Mugilidae: Mugil cephalus, Liza ramada.

Nemachelidae: Oxynoemacheilus leontinae.

Clariidae: Clarias gariepinus.

Cyprinodontidae: Aphanius mento.

Poecilidae: Gambusia affinis.

Blenniidae: Salaria fluvitilis.

A brief summary of the known food composition of fishes:

The most common species, the Bleaks, is a zooplanktivorous feeder through all its life cycle stages; Young stages $(<5 \mathrm{~g})$ of Sarotherodon galilaeus are zooplanktivore whilst older stages are filter feeders which preferably utilize Peridinium if available [20,22], but increased density of zooplankton prey was documented since late 1990's after the decline of Peridinium availability; adults of $\mathrm{O}$. aureus are planktonic filter-feeders, and zooplankton comprised significant component of the food composition. From the mid-1990's Oreochromis aureus is not anymore a significant part of the landings since its stocking was ceased. During the latest 15 years no significant changes of fish feeding habits was documented except increasing of Zooplakton portion in the diet of Sarotherodon galilaeus following reduction of the Peridinium component.

\section{The silver carp case}

Silver carp specimens were introduced into experimental pond aimed at phytoplankton control [23]. The effectiveness of the fishes as phytoplankton control and its effect on the algal community structure were documented. It was found that Microcystis was effectively removed but simultaneously, single-cell nano-phytoplankton density increased. Gut content analysis indicated highest selectivity for 5-20 $\mu$ of 
algal size (mostly colonial Microcystis). Smaller cell size $(<5 \mu)$ phytoplankters,such as Chlamydomonas, and Platymonas were very poorly collected. These filter-feeding Silver Carp caused the phytoplankton size distribution to become smaller. The authors recommend to use Silver carp as a management tool for the removal of large colonies of Microcystis.

The food-web ecosystem of East Lake in Wuhan City, Hubei Province in China [24], is characterized as phytoplanktivorous dominated food-chain where $>90 \%$ of total fish yield is due to Asian Carps (Silver Carp, SC; and Bighead Carp, BH). The lake is annually stocked by fingerlings of those two carps which prominently increased landings (670-750 Kg/ha) compared to SC yield of 4- $5 \mathrm{~kg} / \mathrm{ha}$ in lake Kinneret. SC was defined as phytoplanktivore whilst $\mathrm{BH}$ as an omnivore. It was documented that significant impact of SC on Water quality was done through suppressing and reduction of Cyanobacteria (mostly Microcystis) biomass. The feeding habits of the carps indicates that in the presence of high biomass of SC, when Microcystis is the main food resource, this Cyanophyte was suppressed and did not become dominant component of the phytoplankton biomass. Later on, the biomass of small cell size chlorophytes and diatoms became dominant. This nanophytoplankton served as an optimal food source for grazer zooplankton. The "greens" (small size, chlorophytes and Diatoms) are less suitable as food to SC. From the view point of water quality, managers prefer a lake ecosystem with high biomass of the "greens" accompanied by grazer zooplankton which is a better quality than Microcystis dominance and low biomass of cladocerans.

\section{Fishery}

It is suggested that the potential impact of fishery management and consequently the fish community structure on the plankton is prominent. The fishery influence included algal cell size, species composition and biomass density. The history of fishery management in Lake Kinneret represent prominent conceptual changes. Until early 1980`s fishery maintenance in Lake Kinneret and the impact of fish communities on water quality was not thoroughly incorporated into Lake Management design by managers [8,25,26]. After several years of modern limnological research $[7,16,20,22,27-29]$ a bridging between fishery managers and limnologists was implemented. In other words, successful convincing of fishery managers that the national achievement of domestic water supply from Lake Kinneret depends on lake water quality, which is among other parameters also affected by fish, was done. Moreover, water managers also recognized that fishery is an income resource and must therefore be considered accordingly. Evaluation of 50 years of fisher landings data indicates the following trends: decline of Barbels throughout the entire period. Barbels are native and non-stocked species with a moderate commercial value and therefore market demands are low; Bleaks fishery is strictly market demand-dependent and therefore the prominent commercial value reduction caused a sharp decline of fishery from 1000t/year to negligible landings since early 1980's. Tilapia (Sarotherodon galilaeus, and Oreochromis aureus,) fishery is highly correlated to stocking and natural population periodical cycles. The stocking of 0 . aureus was stopped in the mid 1980's and that of S. galilaeus was reduced recently, landings of both were decreased since the mid-1980's. Silver Carp and Mugilids are both non-native species in Lake Kinneret; therefore their landings is significantly correlated only with their stocking, and decline of introduced fingerlings was followed by landing decline of both species. Fshery management is a fisher income resource and therefore marketdependant, a conflict of interest might be initiated. As a result of collaborative understandings and the previous construction of bridging between fishery biologists and limnologist, an adhoc parity committee was created for the decision-making of fishery management. This committee verified and signed a long-term master-plan for stocking policy and in annual meetings issues of fishery and introductions are fluently discussed and resolved. Top informative priority of "supported management decision" is given to the knowledge of the fish feeding habits

\section{Metabolic trait}

Temperature is widely known as a dominant factor affecting the metabolic activity of poikilotherm Phytoplankton, Zooplankton and fish organisms. Metabolic parameters of zooplankton in Lake Kinneret were measured under three thermal common ranges in the Lake Epilimnion: $15-20^{\circ} \mathrm{C}$ in winter, $20-24^{\circ} \mathrm{C}$ in spring and fall and $24-28^{\circ} \mathrm{C}$ in summer. It was found that the respiration and food intake rates of herbivorous cladocerans is $170 \%$ and $288 \%$ higher in spring and summer than in winter, respectively. Nevertheless, metabolic efficiency is lower in summer by $46 \%$ compared with winter value. The higher summer rates of respiration and food intake by algal consumers (Cladocera) encourage zooplankters to eat more algae but gain less metabolic energy. If herbivorous cladocerans prefer small size algal cells and enhance grazing in summer it is not impossible that the relative abundance of small cell algae in summer would be higher than their relative abundance in winter as a result of grazing trait indirectly related to temperature. The filter-feeding trait and the size selection habits of Daphnia were widely documented [30-34]. The higher relative abundance of large cell size algae in summer is due to the temperature elevation impact on grazing-metabolic behavior and probably not to the physiological properties of the plant. The metabolic activity of the herbivore is temperaturedependent: the small size algae are more efficiently removed by increased razing rate and the density of large cell algae, therefore, increase. The smaller the algal cell is, the better it is ingested and digested.

\section{Kinneret plankton}

Zooplankton: The paper focuses on data collected routinely in Lake Kiinneret. Data source is the Kinneret Limnologicl Laboratory Data Base 1970-2001 [30]. The following parameters were evaluated: Biomass density $\left(\mathrm{g} / \mathrm{m}^{2}\right)$ of Chlorophyta; Zooplankton - Cladocera, numerical densities; For Cladoceran evaluation "Large" (neonates 4 and 5) and "Small" (neonates 1,2, and 3) organisms were sorted. Chlorophyll concentration. Published data from literature is included as well. Two statistical methods that were used for data evaluation are presented here: Linear regression and Fractional Polynomial prediction. 


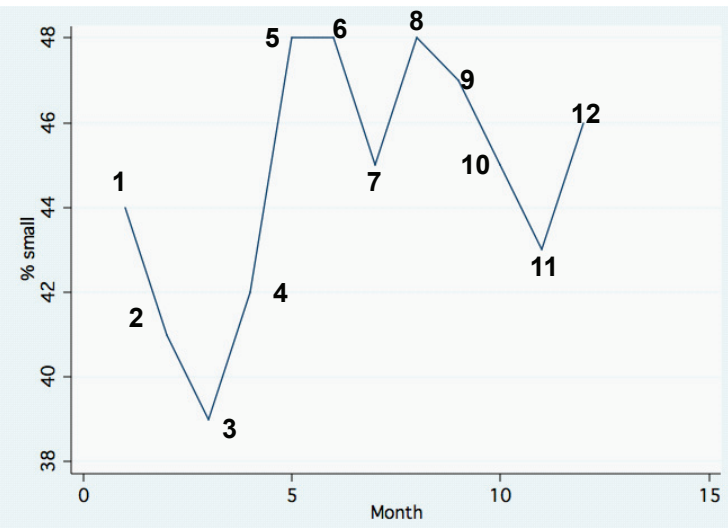

Figure 1: Line scatter of monthly averages(1979-1985) of \% of small cladocerans.
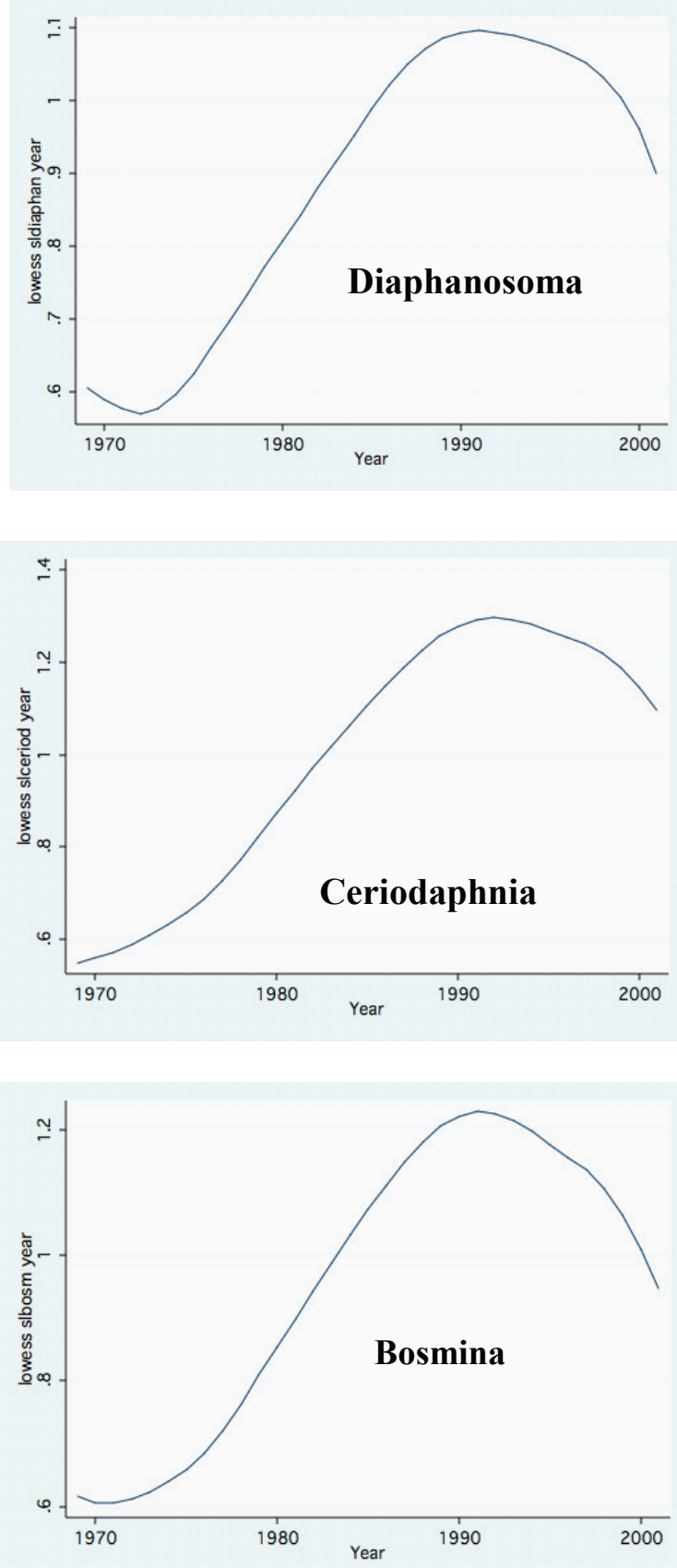

Figure 2: Annual (1969-2001) averages (No./L) of the Ratio between Small and Large (see text) Cladocerans LOWESS (0.8).

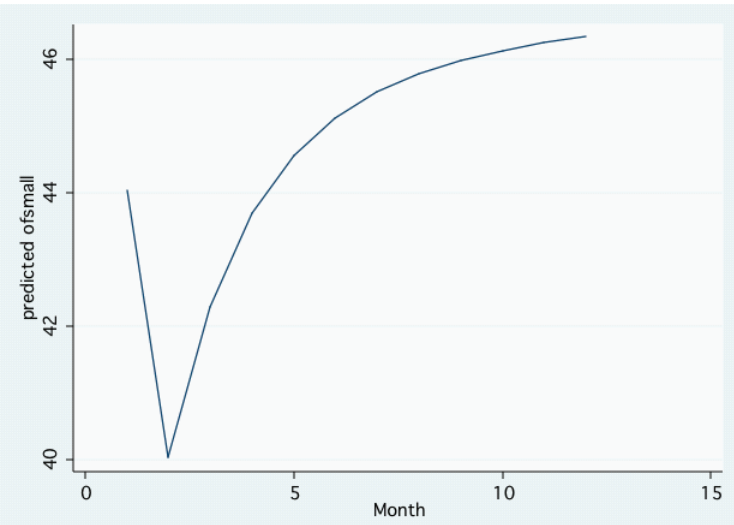

Figure 3: Fractional Polynomial Prediction of monthly \% values of small Cladocerans within total Cladocera density (No/L) In Lake Kinneret during 19791985

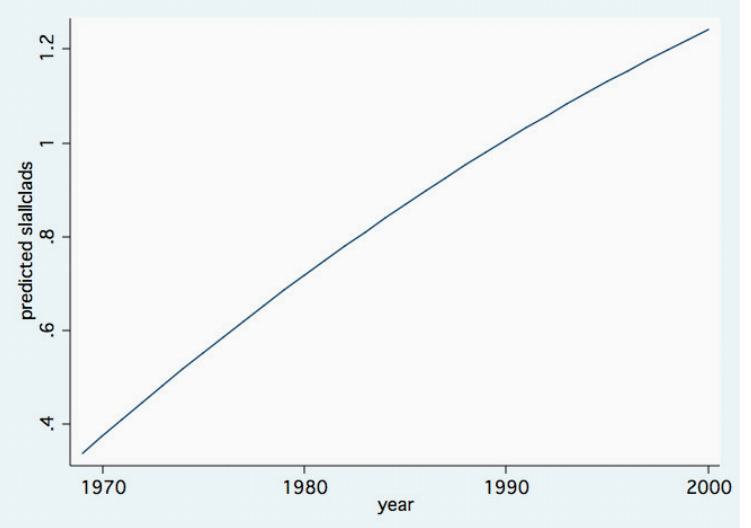

Figure 4: Fractional Polynomial Prediction of \annual averages of the Ratios Small/Large cladocerans density (No/L)In Lake Kinneret during 1969-2001.

Cladoceran Samples Treatment: Samples were collected on a bi-weekly basis in 5-7 sampling stations. Sample treatments and counts are given by Gophen and Azoulay. The following cladocerans were accounted for: Diaphanosoma brachyurum. Bosmina longirostris, Bosmina longirostris Var. cornuta, Ceriodaphnia reticulata, Ceriodaphnia rigaudii. Chydorus sphaericus and Moina rectirostris. "Small" (neonates 1,2,3) and "Large" (neonates 4,5) Cladocerans were sorted and recorded (no/l) and averaged monthly. The percentage of Small within total cladocerans were calculated on a monthly basis and data were assembled seasonally: Winter: January-June and Summer: July -December.

Seasonal changes of the ratio between Small and Large individuals of Cladocera indicates a long-term (1969-2001) relative increase of small organism densities (Figures 1-4). The increase ratio of Small/Large (S/L) cladocerans was caused by increase zooplanktivory of stock enhancement of the Bleak population in the lake, until the late 1990's when abundance declined slightly followed by S/L ration decrease. The summer decline of total cladoceran densities (No./L) as averaged for the period 1970-2001 is presented in figures 5,6. Cladoceran densities are high in Winter and low in Summer. Previous studies [20], documented that preferred food resources are related to algal distribution in Lake Kinneret. The analysis of 
cladoceran gut content confirmed that the majority of the food content is due to algal species smaller than $20 \mu \mathrm{m}$ and their biomass is sufficient for the growth maintenance of cladocerans. Among most common algal genera identified in the cladoceran gut content were Cosmarium, Tetraedron, Chlorococcus. Consequently, the seasonality of nano-phytoplankton biomass $\left(\mathrm{g} / \mathrm{m}^{2}\right)$, chlorophyll concentration and cladoceran metabolic activity should be considered as a significant parameter to be integrated within the discussion presented. Figures 7 indicate an inverse relation between chlorophyll concentration and the biomass of Chlorophyta: chlorophyll decline and the biomass of Chlorophyta increase in summer. The cell size distribution within the nano-phytoplankton assemblages $(<20 \mu \mathrm{m})$ is diversified and the enhanced summer metabolic rate of the

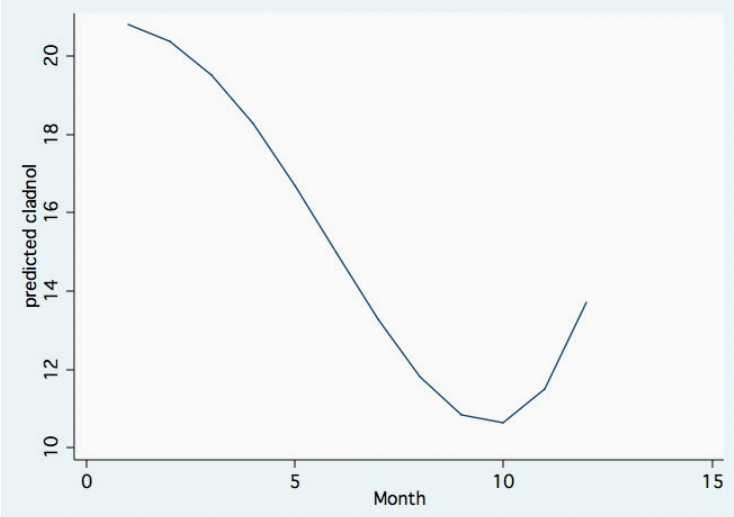

Figure 5: Fractional Polynomial Prediction of monthly averages of total Cladocera density (No/L) in Lake Kinneret During 1969-2001.

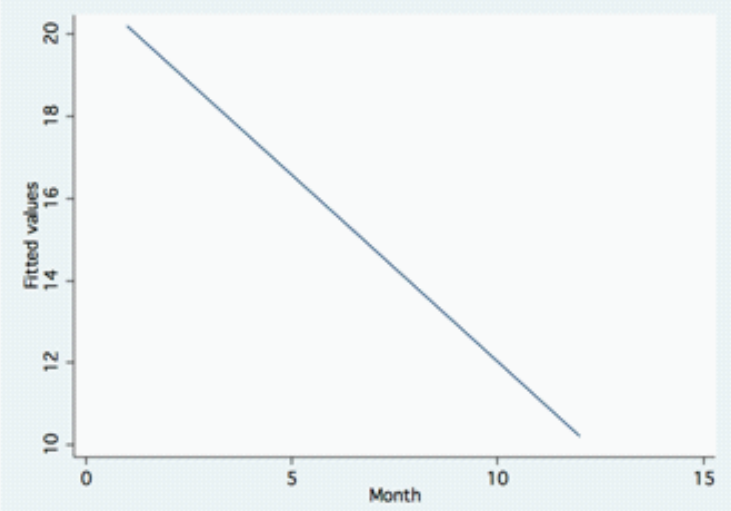

Figure 6: Linear Regression between time (months) and monthly averages of total Cladocera density (NO/L) in Lake Kinneret during 1969-2001.

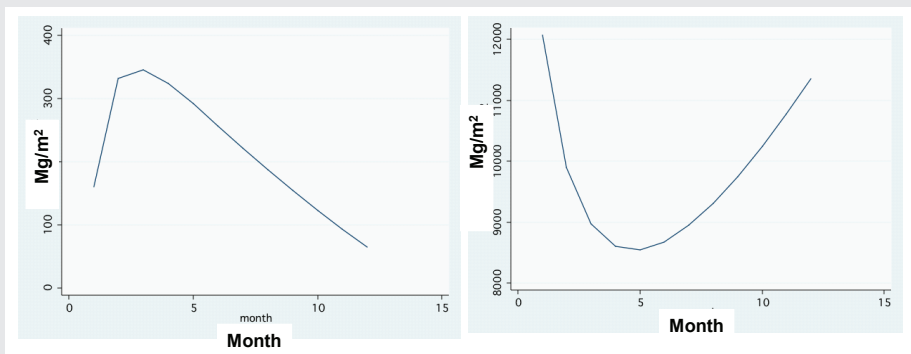

Figure 7: Monthly averages (1970-2001) of Chlorophyll (mg/m2) (left panel) And Chlorophyta (mg(ww)/m2) (right panel) In Lake Kinneret. grazers might be the reason for the higher grazing pressure on the larger algal size, and the leftover tiny algae defines a smaller community mean cell size. The specific chlorophyll content per cell in smaller chlorophytes is probably higher [20], but the grazers prefer the larger ones selectively, Geller 1975 [30-34]. Therefore, the portion of the larger chlorophytes is increasing and chlorophyll concentration declines in summer, but the larger chlorophyte enhances biomass increase and the majority of the community comprised of smaller organisms. Data shown in figure 5 support those given assumption by confirming the enhancement of "small" cladoceran individuals in summer, which means grazing enhancement.

In Lake Kinneret, there is a similarity of the summerwinter body size distribution changes between zooplankton and phytoplankton: smaller in summer and bigger in winter. Until the mid-1990's the dominant phytoplanktonic species in Lake Kinneret was a large $(30-90 \mathrm{~mm})$ cell winter-spring bloom forming Peridinium whilst small cells of nano-phytoplankton dominated the summer assemblages. The density of smaller cladocerans was lower in winter months when fish predation pressure is low and larger cladocerans density increased. The direct and indirect impact of temperature on the body size of either Phytoplankton or zooplankton was widely documented. Nevertheless, several other environmental parameters are also known to have a direct impact on body size. For phytoplankton, selective grazing and size dependence are very effective as fish predation affecting zooplankton body size. The dynamic of nutrient availability and composition are important parameters affecting the cell size of phytoplankton in Freshwaters and Marine environments. In Lake Kinneret, Nitrogen availability decline enhanced large cell Peridinium decline while enhancement of the zooplanktivore Bleak population resulted in a reduction of zooplankton body size in summer due to large size predation preference. Consequently, the elimination of certain environmental factors and preference for others is a misleading attitude for the analysis of seasonal changes in body size by only one parameter - temperature. The zooplankton community structure in lakes comprised of Cladocera, Copepoda and Rotifera. In Lake Kinneret, the Copepoda community is a mixed age population including small Nauplius and large copepodite and adults, and age composition is seasonally changed. These age composition fluctuations are due to the temperature impact of time development of life-cycle stages and lifespan. This paper is focused on the individual growth rate of cladocerans and algal cell size, ignoring life cycle development.

The climatological region of the Kinneret Ecosystem is sub-tropical: nutrient rich-short-wet-and cold winter and nutrient limited-long-hot and dry summer. Because the Kinneret summer conditions are nutrient-limited, one can indicate that nutrient limitation dictates small algal cell size with high temperatures support. The warm summer conditions affect zooplankton predation by fish, which eliminates selectively larger cladocerans and enhances the relative density of smaller ones. The summer temperatures enhance the metabolic activity of Poikilotherm animals, resulting in smaller body size due to the reduction of energy contributed 
for growth. The model construction aimed at Phytoplankton organisms is smaller in summer and larger in winter; this is partly misleading if the involvement of several dependants is not considered. Accepted verification requires an experimental approach because field data could be deceptive and misleading as sole evidence. The metabolic activity of phytoplanktonic algae intensified in summer expressed as shorter doubling time. It was documented that in Lake Kinneret the nanophytoplankton means doubling time is one day or less and that of large cell Peridinium in winter-spring is about three days [20]. Additional pressure on body size comes from the enhancement of grazers pressure, which selectively feeds on the larger nano-phytoplankters, Geller 1975 [30-34]. Summer enhancement of algal metabolism and selective grazing by zooplankton both support a higher density of smaller algae in summer. The metabolic rates of zooplankton have a similar influence: under low winter temperature the metabolism is lower and metabolic efficiencies are higher, resulting in a larger body size. Consequently, lower temperatures might be considered as causation for larger body size and vise versa. Many studies confirmed this model and have been implemented for geographic gradients [35,36], zooplankton body size become smaller along the Pole-Equator gradient. Two similar trends are considered for Poikilotherm plankton organisms: seasonal (winter-summer) and geographic (Pole-Cold - Equator-Warm gradient) where temperature is probably the leading indirect factor and locally other parameters are directly involved.

\section{Phytoplankton}

The complex interaction between phytoplankton cell size and the environment was widely investigated. The common conclusion was focused on the wide spectrum of influenced eco-forces. Acevedo-Trejos et al., [37], studied how size composition of phytoplankton communities relates to Primary Production and its transfer along a latitudinal gradient. They suggested that the trade-off between the high affinity of smaller to nutrients and reduces the vulnerability to grazers of the larger ones is the major driving force of the body size trait. The environmental trade-offs are the key factor that defines the phytoplankton community size composition. Therefore, it can be suggested that the dominance of small over large algal cell size in the summer Kinneret ecosystem might be attributed to nutrient limitation together with predation avoidance. On the contrary, with implication to freshwater (Lake Kinneret), the smaller body size of cladocerans might be the result of increased metabolic trait influenced by higher temperature. Fundamental differences between the freshwater and marine Diatoms in cell size distribution were reported by Litchman et al., [38]. Marine diatoms are significantly larger than freshwater diatoms. They [38], attributed those differences to Nitrogen vs Phosphorus limitation, as well as fluctuation and mixing layer regime. $\mathrm{N}$ and $\mathrm{P}$ increase in availability resulted in small size enhancement while pulses of $\mathrm{N}$ initiated large cells. The comprehensive approach indicates the combined influence on diatom cell size of nutrient limitation, sinking rate, and the depth of mixing layer. The diversity of diatoms cell size is the dependant of a combination between nutrient $(\mathrm{N}, \mathrm{P})$ availability and physical trait either in freshwater or in the marine environment. In freshwater monomictic Lake Kinneret, stable thermal stratification (high RTR values) is the outcome of subtropical conditions: Eight month length of pilimnetic warm (27-28 ${ }^{\circ} \mathrm{C}$ mean) temperatures and zero precipitation in summer. Nevertheless, during most of those summer days, a strong $(2-10 \mathrm{~m} / \mathrm{s}$ velocity) west-wind blows during about 8 hours a day, producing efficient mixing of the upper layers. Conclusively, nutrient limitation, stable stratification and intensive grazing pressure are significant conditions for the development of a small range of cell size. It is highly probable that, in other monomictic freshwater lakes in summer, algal cells are small.

\section{Phytplankton vertical migration}

Nutrient availability is not only concentration-dependent. Several options are known as supporters of enhanced resources availability, not by concentration change but by maintaining diurnal or seasonal vertical migration (motility) of the algal cell [39]. The Increase of nutrient availability might be the result of larger cell size migratory capability. Mariani et al., [39], documented seasonal alternatives between non-motile diatoms in spring and motile flagellates during summer. This alteration changes zooplankton grazing strategy as well as nutrient availability. Consequently, phytoplankton motility might be a factor of the change in cell size community structure. Dinoflagellates, in both marine and freshwater ecosystems, are well-known motile organisms. The daily vertical migration of Peridinium was documented. The motility of Peridinium in Lake Kinneret was accounted as an adaptive factor aimed at nutrient supply and improvement of light and thermal conditions caused by large cell size development. It is also suggested that nutrient limitation, thermal structure and wind-generated horizontal currents in summer prevent vertical migration of the Peridinium cells, causing large cells to diminish and small cell size to flourish.

\section{Allometric study of phytoplankton cell size}

The Allometric approach to the study of the relationship between body size and physiological behavior was documented by Verdy et al., [40]. Phytoplankton cell size as a competitive ability was studied in a chemostat model [40]. Large phytoplankton cells may be favored when their growth is limited by the rate at which the internal stock of organic matter is converted into biomass. If the rate at which internal stocked energy is converted to biomass is higher, the cell size is larger and the nutrient uptake kinetics is a metabolic trait. Consequently, it is suggested that, if nutrients are unlimited, grazing parameter does not exist, and temperature-induced physiological trait of biomass production cells are large.

There is one significant difference between freshwater and marine ecosystems: freshwater ecosystems are commonly more productive as a result of higher nutrient availabilities. The Oligotrophic status is less abundant in freshwater while Eutrophic status is less common in oceans. Therefore, the discussion about algal cell size interrelation to nutrient availability cannot be directed generally to freshwater or marine ecosystems but should be attributed to the trophic 
status of the body of water. A study of the impact of nutrient supply on algal cell size was presented by Cloen [35]. A general formulation indicated that phytoplankton biomass and production in the oceans are dominated by small cell size Picoplankton and large cells dominate in surface waters, which are enriched with nutrients by deep water mixture $[41,42]$. The dominance of small cell is due to Oligotrophism accompanied by low grazing pressure under a temperature elevation of $5^{\circ} \mathrm{C}$. Cloen's [35], conclusive statement is similar to what was shown in freshwater, Geller 1975, [30-34]. 1). Large cells are grazed slower than smaller cells and 2) Grazing rate increase by Temperature elevation is faster than algal growth rate [43]. In a changing world where atmospheric $\mathrm{CO}_{2}$ and Temperature increase, as well as ocean chemistry, circulation, light and nutrient regimes are modified, the oceanic phytoplankton cell size is suitable for tracking those global changes [44]. A study suggested that eco-physiological trait, such as cell size and elemental stoichiometry of marine phytoplankton, are suitable parameters that reflect global changes. The attribute of marine phytoplankton cell size solely to seasonal changes of temperature might be a misleading approach [45-50].

\section{Conclusive remarks}

Phytoplankton cell size, either in freshwater or in oceanic ecosystems, is a dependant of complex interactions. The complexity of those relations is affected by chemical, physical, and biological parameters. Among Chemical factors: nutrients composition and availability.

Among Physical factors: Temperature, water-specific gravity, turbulence, upwelling, Water mass horizontal and vertical movements, currents, seich, light conditions, and others. Among known diversities of the feeding behavior of Zooplanktivorous fish, two types are common: Filter feeders (Tilapias) and particulate visual attackers (Bleaks). The filter feeder fishes ingest non-selective size particles. The particulate feeders select the larger organisms because "larger sizes are better indicated" and, therefore, more vulnerable

The simple seasonal split of the cell size diversity trait is, therefore, incomplete and partly biased. In some of the planktonic organisms, the summer size class is due to a smaller level while in others it is due to a larger size. The conclusively suggested approach is the need to produce a comprehensive analysis including known chemical, physical and biological conditions of the evaluated ecosystem.

High summer temperatures are undoubtedly affecting different processes such as metabolic behavior, feeding habits, and others. But since ecological ecosystems comprised of complex interactions, the results might be opposed, small or large size of cell or organism body size. It was widely documented that phytoplankton cell size is smaller in summer and larger in winter. The response to the question why? is: because it is a multi parameters complicated system. Two major reasons are relevant: 1) selective consumption grazing by fish and zooplankton; and 2) elevated temperature induce higher intensity of metabolic trait in summer. Comparative definition of impact level require experimental approach.

\section{References}

1. Peter RH (1993) The Ecological Implications of Body Size, Cambridge University Press. 329.

2. Thiel H (1975) The size structure of deep-sea benthos. Internationale Revue der Gesamten Hydrobiologie 60: 575-606.

3. Threlkeld ST (1976) Starvation and the size structure of zooplankton communities. Freshwat. Biol 6: 489-496. Link: https://bit.ly/2X4IWdR

4. Kilham P, Kilham SS (1980) The evolutionary ecology of phytoplankton The Ohysiological Ecology of Phytoplankton, L. Morris, ed 571-597. London: Blackwell Publisher.

5. Semina HJ (1972) The size of Phytoplankton cells in the pacific Ocean Internationale Revue der Gesamten Hydrobiolofie 57: 177-205. Link: https://bit.ly/2Jbl3MR

6. Zohary T, Naselli-Flores L, Alster A, Fishbein T (2018) Being smaller in summer larger. in winter: a general pattern in freshwater phytoplankton. Migal weekly seminar. in winter: a general pattern. i. in freshwater phytoplankton. Miga weekly seminar. ii. (18.11.2018) un published data.

7. Ben-Tuvia A (1978) Chapter, Fishes, in: Lake Kinneret Monographiae Biologicae (C. Seruya ed), Junk Publisher 407-430.

8. Bruton MN, Gophen M (1992) The Effect of Environmental Factors on the Nesting and Courtship of Tilapia zillii in Lake Kinneret, (Israel). Hydrobiologia 239: 171-178. Link: https://bit.ly/31 VmgQE

9. Gophen M (2017a) Experimental Study of the Feeding habits of Tilapia zillii (Gervais) in Lake Kinneret. Open Journal of Modern Hydrology 7: 1-10. Link: https://bit.ly/2FtFbIQ

10. Spataru P, Viveen WJAR, Gophen M (1987) Food Composition of Clarias gariepinus (= C lazera) (Cypriniformes, Clariidae) in Lake Kinneret (Israel). Hydrobiologia 144: 77-82. Link: https://bit.ly/31UmGa3

11. Drenner RW, Hambright JD, Vinyard GL, Gophen M, Pollingher U (1987) Experimental Study of Size-Selective Phytoplankton Grazing by a FilterFeeding Cichlid and the Cichlid's Effects on Plankton Community Structure. Limnol. Oceanogr 32: 1138-1144. Link: https://bit.ly/2LhHbal

12. Gophen M (2017b) Fish-Zooplankton - A Predator-Prey Relations as a Key Factor for the Design of Zooplankton Distribution Sampling Program in Lake Kinneret, Israel. Open Journal of Modern Hydrology 7: 209-222. Link: https://bit.ly/2J73fCj

13. Gophen M, Landau R (1977) Trophic Interactions Between Zooplankton and Sardine (Mirogrex terraesanctae) Populations in Lake Kinneret, Israel. Oikos 29: 166-174. Link: https://bit.ly/2NeeQVD

14. Gophen M, Drenner RW, Vinyard GL (1983a) Fish Introduction into Lake Kinneret - Call For Concern. Fish Mgmt 14: 43-45. Link: https://bit.ly/2Yd7rXo

15. Gophen M, Drenner RW, Vinyard GL (1983b) Cichlid Stocking and the Decline of the Galilee St. Peter's Fish (Sarotherodon galilaeus) in Lake Kinneret (Israel). Can J Fish Aquat Sci 40: 983-986. Link: https://bit.ly/2ZMhHGM

16. Gophen M, Pollingher U (1985) Relationships Between Food Availability, Fish Predation and the Abundance of the Herbivorous Zooplankton Community in Lake Kinneret. Arch Hydrobiol Beih Ergebn Limnol 21: 397-405.

17. Gophen M, Threlkeld ST (1989) An Experimental Study of Zooplankton Consumption by the Lake Kinneret Sardine. Archiv Hydrobiol 115: 91-95.

18. Gophen M (2018) Reforming Provisional (2007-2008) Sarotherodon galilaeus Landing Decline in Lake Kinneret Isreal. Open Journal of Modern Hydrology 8: 13-27. Link: https://bit.ly/2IlwLiG

19. Landau R, Gophen M, Walline P (1988) Larval Mirogrex terraesanctae (Cyprinidae) of Lake Kinneret (Israel): Growth Rate, Plankton Selectivities, Consumption Rates and Interactions with Rotifers. Hydrobiologia 169: 91 106. Link: https://bit.ly/2Yc5cDO 
20. Serruya CM, Gophen, Pollingher U (1980) Lake Kinneret: Carbon Flow Patterns and Ecosystem Management. Arch Hydrobiol 88: 265-302. Link: https://bit.ly/2X1XECf

21. Spataru P, Gophen M (1985) Feeding Behaviour of Silver Carp (Hypophthalmichthys molitrix) (Val.) and its Impact on the Food Web in Lake Kinneret, Israel. Hydrobiologia 120: 53-61. Link: https://bit.ly/2XxLLYV

22. Landau R (1975-1977) The Fish Population of Lake Kinneret; Project Report; Israel Oceanographic and Limnological Research Co. LTd. Haifa Israel 13.

23. Ma H, Cui F, Liu Z, Fan Z, He W, et al. (2010) Effect of filter-feeding fish silver carp on phytoplankton species and size distribution in surface water: a field study in water works. J Environ Sci (China) 22: 161-167. Link: https://bit.ly/2Fsu0Af

24. Miura T (1989) East Lake: A Phytoplanktivorous Fishes Dominated Lake Ecosystem; Otsu Hydrobiological Station, Kyoto Unuversity,No 334, 142.

25. Gophen M (2014) Competitive consumption of the Lake Kinneret (Israel) plankton by Hypophthalmichthys molitrix and Sarotherodon galilaeus. Open Journal of Ecology 4: 532-542. Link: https://bit.ly/2XAEGa0

26. Gophen M, Snovsky G (2015a) Silver Carp (Hypophthalmichthys molitrix,Val. 1844) Stocking in Lake Kinneret (Israel). Open Journal of Ecology 5: 343-351 Link: https://bit.ly/2KBBUeN

27. Gophen M (1984) The Impact of Zooplankton Status on the Management of Lake Kinneret (Israel). Hydrobiologia 113: 249-258. Link: https://bit.ly/2IKU63A

28. Gophen M (1986) Fisheries Management in Lake Kinneret (Israel). IN: Proc Annual Meeting North American Lake Management Society, Lake Geneva, Wisconsin, USA. 327-332. Link: https://bit.ly/2X43WGw

29. Gophen M (1987) Fisheries Management, Water Quality and Economic Impacts: A Case Study of Lake Kinneret. Proc. World Conference on Large Lakes, Mackinac Island, Michigan, USA. 2: 5-24.

30. KLL-IOLR LKDB (1970-2013) Kinneret Limnological Laboratory, IOLR Annual Reports Lampert, W. 1987, feeding and nutrition in Daphnia. Mem.Ist Ital Idrobiol 45: 143-192.

31. Lampert W (2006) Daphnia: Modelherbivore, predator and prey. Pol.J Ecol 54 607-620. Link: https://bit.ly/2ILpLld

32. Lampert W (2011) Chapter: Testing Concepts and Hypothesis, Chapte in: Daphnia: Development of a Model Organism in Ecology and Evolution. International Ecology Institute Nordbunte 23, 21385 Olendorf/Luhe Germany. 19-45. Link: https://bit.ly/2ZLv9dJ

33. Gliwicz M (1980) Filtering rats, food size selection and feeding rates in cladocerans-another aspectof interspecific competition in filter-feeding zooplankton. Evolution and Ecology of Zooplankton Communities. 282-291. Link: https://bit.ly/2XwEV5X

34. Dodson SI (1970) Complementary feeding niches sustained by size-selective predation. Limnol. Oceanogr 15: 131-137. Link: https://bit.ly/2FwR2Wq
35. Cloen JE (2018) Why large cells dominate estuarine phytoplankton. Limno Oceanogr 63: 392-409. Link: https://bit.ly/2NehWc3

36. Maranon E, Hilligan PM, Barclela R, Gonzales N, Mourino B, et al. (2001) Patterns of Phytoplankton size structure and productivity in contrasting open-ocean environments. Inter Research MEPS 216: 43-56. Link: https://bit.ly/2X877wL

37. Acevedo-Trejos EE, Maranon, Merico A (2018) Phytoplankton size diversity and ecosystem function relationships across oceanic regions. Proc Biol Sci 285. Link: https://bit.ly/2NdgerB

38. Litchman E, Klaumeier CA, Yoshiyama K (2009) Contrasting size evolution in marine and freshwater diatoms. PNAS 106: 2665-2670. Link: https://bit.ly/2Y8IWe5

39. Mariani P, Andersen KH, Visser AW, Barton AD, Kiorboe T (2013) Control of plankton seasonal succession by adaptive grazing. Limnbol. Oceanogr 58 : 173-184. Link: https://bit.ly/2Ydi7W1

40. Verdy A, Follows M, Flierl G (2009) Optimal Phytoplankton cell size in an allometric model. Inter Research MEPS 379: 1-2. Link: https://bit.ly/2RBdFO

41. Hirata T, Aiken J, Hardman-Mountford N, Smyth TJ, Barlow RG (2008) An absorption model to determine phytoplankton size classes from satellite ocean colour. Remote Sensing of Environment 112: 3153-3159. Link: https://bit.ly/2FzfjeN

42. Kiorboe T (1993) Turbulence, Phytoplankton Cell Size, and the Structure of Pelagic Food Webs. Advances in Marine Biology 29: 1-72. Link: https://bit.ly/2RzIB1D

43. Hansen PJ, Bjornsen PK, Hansen BW (1997) Zooplankton grazing and growth: Scaling within the 2-2, $-\mu \mathrm{m}$ body size range. Limnol. Oceanogr 42: 687-704. Link: https://bit.ly/2ZRWFqf

44. Finkel ZV, Kevin JB, Quigg FA, Reesv TAV, Raven JA (2010) Phytoplankton in Changing World: cell size and elemental stichoiometry. Journal of Plankton Research 32: 119-137. Link: https://bit.ly/2Lik2oE

45. Gophen M, Snovsky G (2015b) Mugilids (Mugil cepalus, Linnaeus 1758 Liza ramada, Riss 1810) Stocking in Lake Kinneret (Israel). Open Journal of Ecology 5: 389-399. Link: https://bit.ly/2J7BaL0

46. Pisanti S (2005) Quasi-Cyclic fluctuationbs in St. Peter's Fish landings in Lake Kinneret -Continues. Fisheries and Fish breeding in Israel. 1: 777-781. Link: https://bit.ly/2XvnNO9

47. Serruya C (1978) Lake Kinneret, Monographiae Biologicae, Junk Publisher 32: 501

48. Walline P, Ostrovski I (1987-2016) KLDB - Kinneret Limnological Laboratory IOLR, Annual Reports, Chapter: Fish Populations.

49. Walline P, Pizanty S, Gophen M, Berman T (1993) The Ecosystem of Lake Kinneret, Israel. ICES.C.M. 1990/L: 39:1-8.

50. Zohary T (2004) Changes of the Phytoplankton assemblages of Lake Kinneret after decades of predictable repetitive pattern. Freshwater Biology 49: 13551371. Link: https://bit.ly/31Ud2Eh

Copyright: (c) 2019 Gophen M. This is an open-access article distributed under the terms of the Creative Commons Attribution License, which permits unrestricted use, distribution, and reproduction in any medium, provided the original author and source are credited. 